\title{
Investigation of Antidiarrheal Activity of the Aqueous Leave Extract of Ficus asperifolia in Rats
}

\author{
Emmanuel TF1*, Momoh S2, Olasupo $\mathrm{AS}^{3}$, Dare $00^{4}$ and John $\mathrm{E}^{2}$ \\ ${ }^{1}$ Department of Medical Biochemistry, Kogi State University, Nigeria \\ 2Department of Biochemistry, Faculty of Natural Sciences, Kogi State University, \\ Nigeria \\ ${ }^{3}$ Department of Physiology, College of Health Sciences Benue State University, Nigeria \\ ${ }^{4}$ Department of Anatomy, Kogi State University, Nigeria
}

\section{Research article \\ Volume 3 Issue 3}

Received Date: June 11, 2018

Published Date: July 02, 2018

*Correspondence author: Emmanuel T Friday, Department of Medical Biochemistry, Faculty of Basic Medical Sciences, College of Health Sciences, Kogi State University, P.M.B 1008, Anyigba, Kogi State, Nigeria, Tel: +2348069608367; Email: emmfriday@gmail.com

\section{Abstract}

Ficus asperifolia (FA) has been recommended locally for several disorders including diarrhea. Although various work had been done on Ficus asperifolia but not on it antidiarrhea activity. The objective of this research is to investigate the antidiarrheal activity of the aqueous leave extract of Ficus asperifolia in rats. This is to substantiate the traditional claim of the antidiarrheal activity of FA. The effect of aqueous leave extract of Ficus asperifolia on castor oil-induced diarrhea, castor oil-induced enteropooling, and gastrointestinal motility test using activated charcoal meal method were examined. The extract was first assayed for its effects in castor oil-induced diarrhea at different doses (400, and 800mg/ $\mathrm{kg}$, p.o.) in which significant activity $(\mathrm{p}<0.05)$ was observed at a dose of $800 \mathrm{mg} / \mathrm{kg}$. Hence, the dose was been used as the working dose in the other models. In induced Enteropooling and Intestinal motility, there was a significant reduction in secretion and distance travel by marker respectively. The result shows that aqueous leave extract of FA have an antidiarrheal activity by inhibiting secretion and intestinal motility.

Keywords: Aqueous extract; Antidiarrhea; Oil-induced; Enteropooling; Receptor blockedes

Abbreviations: ORT: Oral Rehydration Therapy; PCV: Packed Cells Volume; AQFA: Aqueous Extract of Ficus asperifolia.

\section{Introduction}

Diarrhea account for more than 5million death of children under five, especially in developing countries [1] and despite the undeniable success of Oral Rehydration Therapy (ORT), acute diarrhea remains a leading cause of childhood deaths [1,2]. The greatest number of deaths from diarrhea occurs in south Asia and Africa and the disease is worsened by lack of access to clean water, malnutrition and hygienic disposal of human waste [3]. 


\section{International Journal of Biochemistry \& Physiology}

The use of medicinal plants is an age-long practice in various parts of the world for both curative and preventive measures [4]. Recently, there has been a great interest in herbal remedies for the treatment of a number of ailments including diarrhea [5] and in many African countries, herbal drugs are used in treating diarrhea especially in rural areas. Today it is estimated that about $80 \%$ of the world population rely on plant extracts as medicine to meet their health needs [4]. According to the statement of World Health Organization (WHO), medicinal plants would be the best source from which to develop a variety of medications for diarrhea [1].

Ficus asperifolia has the traditional claim of having antidiarrheal activity, but the potency and efficacy has not been scientifically determined. This research work was carried out to evaluate the antidiarrheal activity of aqueous extract of Ficus asperifolia (AQFA) in order to proof the traditional claim scientifically. Ficus asperifolia is a small size plant belonging to the family Moraceae. It is an epiphyte and a terrestrial plant which can reach a height of $20 \mathrm{~m}$. It is widely distributed in Nigeria, Senegal, Tanzania, Chad, Guinea-Bissau, Sierra Leone and many other African countries. The leaves are enormous and displayed spirally, the branches have the shape of ellipse and the roots are most of Ficus asperifolia is a highly medicinal plant that has been used in traditional medicine for the treatment of diseases, such as wound and diabetes [6]. Literatures reveal that Ficus asperifolia possess many pharmacological and physiological activities [7]. Recent studies reveal that oral $\mathrm{LD}_{50}$ of aqueous leave extract of Ficus asperifolia is higher than $4000 \mathrm{mg} / \mathrm{kg}$ b. wt. Therefore, Ficus asperifolia can be categorized as highly safe since substances having $\mathrm{LD}_{50}$ higher than $50 \mathrm{mg} / \mathrm{kg}$ are non-toxic [4]. It was recently reported, that administration of aqueous extract of Ficus asperifolia caused a significant decrease in blood glucose concentration of alloxan-induced diabetic rats to normal levels $[8,6]$. It was also reported that aqueous extract of Ficus asperifolia have pro-implantation, pro-development, uterotrophic, and uterotonic-like activities [9]. Administration of Ficus asperifolia extract to rat with phenylhydrazine-induced anemia show increase in PCV (packed cells volume), Hb(hemoglobin), and RBC(red blood cell). All these show that Ficus asperipolia aqueous extract can be used to manage anemic patient [8].

This study was carried out to investigate the antidiarrheal activity of aqueous extract of Ficus asperifolia (AQFA) leaf extract in experimental animal model.

\section{Materials and Methods}

\section{Chemicals, Reagents and Drug}

Castor oil, Normal saline, Loperamide, Atropine sulphate, Propranolol, Prazosin, Nifedipine, was purchased form registered pharmacy Negro Phermancy, Anyigba, kogi State Nigeria. While Tween 80, solvents and other chemicals were purchase from Sigma Chemical Co,Ltd (StLouise USA). All of the chemicals and reagent were of analar grade.

\section{Plant material}

The fresh leaves of Ficus asperifolia were collected from Egume and Kogi State University Anyigba campus in Dekina Local Government, Kogi State, Nigeria. The plant was identified and authenticated by Taxonomist, in the Department of Biology, Faculty of Natural Sciences, Kogi State University, Anyigba, Nigeria. The sample was kept in the laboratory prior to the use.

\section{Animals}

Healthy Wistar albino rats of either sex weighing 100$150 \mathrm{~g}$ were obtained from Animal House, College of Health Sciences, Kogi State University Anyigbakogi, Nigeria.

\section{Plant preparation and Extraction}

The fresh leaves of Ficus asperifolia were washed with distilled water, and air dried in the laboratory at room temperature for four weeks. The plant sample was pulverized with mortar and pestle. A fine powder was obtained using a mortised blender and sieving (of pore). The fine powder was then stored under dried condition prior to use.

Exactly 200g of Ficus asperifolia leaves powder was weighed with the aid of analytical weighing balance and poured into a beaker containing $200 \mathrm{ml}$ of boiling water. The mixture was stirred with stirring rod, covered with a foil paper. After 24hours, vacuum filtration was carried out using vacuum pump. The filtrate in a beaker was evaporated in a beaker in water bath at $100^{\circ} \mathrm{C}$. The concentrated extract was kept in the refrigerator before use.

\section{Experimental Design}

A total of 40 albino Wistar rats were used for this research. The animals were housed under standard 


\section{International Journal of Biochemistry \& Physiology}

environmental conditions (room temperature $26 \pm 1^{\circ} \mathrm{C}$ and relative humidity $45-55 \%$ ), with 12 hours light/dark cycle. They were kept in cages, fed with pelletized feed (vital feed) and allowed free access to water throughout the research. The rats were allowed to acclimatize for two week before the experiments.

The experimental cages were lined with white blotting paper and wire gauze was placed about $2 \mathrm{~cm}$ above the floor. For all the experiments, the animals were fasted for 18 hours with free access to water.

\section{Castor Oil Induced Diarrhea}

The anti-diarrheal activity of aqueous extract of Ficus asperifolia (AQFA) was evaluated accrding to the method described by Teke, et al. [10]. Twenty (20) albino rats of either sex weighing $100-150 \mathrm{~g}$ were used. They were divided into four groups of 5 rats each. The rats were fasted 18hours with free access to water before the experiment. All treatment in this experiment was through the oral route except otherwise stated. Each animal was administered $1 \mathrm{ml}$ of castor oil. Thirty minutes later, animals in the different groups were treated as follows: Group1 was given $10 \mathrm{ml} / \mathrm{kg}$ normal saline; Group2, Loperamide (3mg/kg); Group3, AQFA (400mg/kg); Group4, AQFA $(800 \mathrm{mg} / \mathrm{kg})$. The fecal pellets of the rats were thereafter counted every hour from the time of AQFA treatment for the first 5hours. The presence of wet faeces was noted for each animal. The dose with greater effect on wet fecal pellet output was used as the working dose.

\begin{tabular}{|c|c|c|c|}
\hline Group & $\begin{array}{c}\text { Number of } \\
\text { rats }\end{array}$ & Description & Treatment \\
\hline 1 & 5 & $\begin{array}{c}\text { Induced with } \\
\text { diarrhea }\end{array}$ & $\begin{array}{c}10 \mathrm{ml} / \mathrm{kg} \text { normal } \\
\text { saline }\end{array}$ \\
\hline 2 & 5 & $\begin{array}{c}\text { Induced with } \\
\text { diarrhea }\end{array}$ & $\begin{array}{c}3 \mathrm{mg} / \mathrm{kg} \\
\text { Loperamide }\end{array}$ \\
\hline 3 & 5 & $\begin{array}{c}\text { Induced with } \\
\text { diarrhea }\end{array}$ & $400 \mathrm{mg} / \mathrm{kg} \mathrm{AQFA}$ \\
\hline 4 & 5 & $\begin{array}{c}\text { Induced with } \\
\text { diarrhea }\end{array}$ & $800 \mathrm{mg} / \mathrm{kg} \mathrm{AQFA}$ \\
\hline
\end{tabular}

Table 1: Showing the treatment of the castor oil induced diarrhea.

\section{Intestinal Motility Test}

Twenty albino Wistar rats were fasted for 18 hours and divided into four groups of 5 animals each. Group 1 rats served as control and was administered $3 \mathrm{ml} / \mathrm{kg}$ normal saline (p.o) orally. Group 2 served as positive control, and received atropine sulfate (i.p) intraperitoneally. Group 3 and 4 received the aqueous extract of Ficus asperifolia (AQFA) (400 and $800 \mathrm{mg} / \mathrm{kg}$ respectively) orally. After thirty minutes, all the animals received $1 \mathrm{ml}$ of activated charcoal $(10 \%$ charcoal in Tween 80 ) orally. Thirty minutes later, the animals were sacrificed by cervical dislocation. The abdomen was cut open immediately and the whole small intestine (from pylorus to caecum) was dissected out. The length of the whole small intestine and the distance travelled by the marker (activated charcoal) was measured. This distance was expressed as a percentage of the length of the small intestine [3].

$$
\text { Inhibition }(\%)=\frac{\text { Dcontrol }- \text { Dtreated }}{\text { Dcontrol }} X 100
$$

$\mathrm{D}_{\text {control }}=$ distance travelled in control group

$D_{\text {treated }}=$ distance travelled in treated group

\begin{tabular}{|c|c|c|c|}
\hline Group & $\begin{array}{c}\text { Number of } \\
\text { rats }\end{array}$ & Marker & Treatment \\
\hline 1 & 5 & $\begin{array}{c}10 \% \text { charcoal in } \\
\text { Tween } 80\end{array}$ & $\begin{array}{c}3 \mathrm{ml} / \mathrm{kg} \text { Normal } \\
\text { saline }\end{array}$ \\
\hline 2 & 5 & $\begin{array}{c}10 \% \text { charcoal in } \\
\text { Tween } 80\end{array}$ & $\begin{array}{c}0.1 \mathrm{mg} / \mathrm{kg} \\
\text { Atropine }\end{array}$ \\
\hline 3 & 5 & $\begin{array}{c}10 \% \text { charcoal in } \\
\text { Tween } 80\end{array}$ & $400 \mathrm{mg} / \mathrm{kg}$ AQFA \\
\hline 4 & 5 & $\begin{array}{c}10 \% \text { charcoal in } \\
\text { Tween } 80\end{array}$ & $800 \mathrm{mg} / \mathrm{kg}$ AQFA \\
\hline
\end{tabular}

Table 2: Showing the summary of the intestinal motility test.

\section{Castor oil - induced Enteropooling}

Twenty albino Wistar rats of either sex were used for this experiment. They were fasted for 18 hours and grouped into four groups of 5 animals each. Animals in group 1 served as control and received orally $1 \mathrm{ml} / \mathrm{kg}$ of normal saline. Group 2 served as standard and received $3 \mathrm{mg} / \mathrm{kg}$ Loperamide, while group 3 and 4 received AQFA $(400 \mathrm{mg} / \mathrm{kg}$ and $800 \mathrm{mg} / \mathrm{kg}$ respectively) orally. One hour later, all the animals were administered $1 \mathrm{ml}$ of castor oil orally. After one hour of administration of castor oil, all the rats were sacrificed by cervical dislocation. The abdomen was cut open immediately and the whole of the small intestine was removed and weighed. The fluid content of the intestine was collected and measured. The intestine was re-weighed after collecting the fluid content, and the difference between the full and small intestine was calculated [3]. 


\section{International Journal of Biochemistry \& Physiology}

$$
\text { Inhibition }(\%)=\frac{\text { Wcontrol }- \text { Wtreated }}{\text { Wcontrol }} \times 100
$$

$\mathrm{W}_{\text {control }}=$ weight of intestinal content in control group

$\mathrm{W}_{\text {treated }}=$ weight of intestinal content in treated group

\begin{tabular}{|c|c|c|c|}
\hline Group & $\begin{array}{c}\text { Number of } \\
\text { rats }\end{array}$ & Pre-treatment & Treatment \\
\hline 1 & 5 & $1 \mathrm{ml}$ normal saline & $1 \mathrm{ml}$ of castor oil \\
\hline 2 & 5 & $\begin{array}{c}3 \mathrm{mg} / \mathrm{kg} \\
\text { Loperamide }\end{array}$ & $1 \mathrm{ml}$ of castor oil \\
\hline 3 & 5 & $400 \mathrm{mg} / \mathrm{kg}$ AQFA & $1 \mathrm{ml}$ of castor oil \\
\hline 4 & 5 & $800 \mathrm{mg} / \mathrm{kg}$ AQFA & $1 \mathrm{ml}$ of castor oil \\
\hline
\end{tabular}

Table 3: Show the summary of castor oil - induced Enteropooling.

\section{Statistical Analysis}

The results are presented as mean \pm standard error of mean. T-test was used to calculate the significant differences between two groups. The values were considered significant when $\mathrm{p}<0.05$.

\section{Results}

\section{Effects of Aqueous Extract of Ficus asperifolia on Wet Fecal Pellet Output}

The result shows that administration of castor oil induced diarrhea in all the animals and treatment with aqueous extract of Ficus asperifolia at a dose of $800 \mathrm{mg} / \mathrm{kg}$ significantly $(p<0.05)$ decrease the wet fecal pellet output within the first 5hours after diarrhea was induced using castor oil. The standard drug loperamide $(3 \mathrm{mg} / \mathrm{kg})$ also significantly $(\mathrm{p}<0.05)$ decreased the number of wet fecal pellet with an inhibition of $61.1 \%$ after 5 hours while the inhibition effected by $800 \mathrm{mg} / \mathrm{kg}$ AQFA was $38.9 \%$ as shown in Table 1.

\begin{tabular}{|c|c|c|c|c|c|c|c|}
\hline Group & Treatment & 1hour & 2hours & 3hours & 4hours & 5hours & Inhibition (\%) \\
\hline 1 & Control (NS) & $2.4 \pm 0.22$ & $2.4 \pm 0.22$ & $2.4 \pm 0.22$ & $2.6 \pm 0.24$ & $3.6 \pm 0.36$ & - \\
\hline 2 & Loperamide 3mg/kg & $1.0 \pm 0.2^{\mathrm{a}}$ & $1.4 \pm 0.22^{\mathrm{b}}$ & $1.4 \pm 0.2^{\mathrm{b}}$ & $1.4 \pm 0.22^{\mathrm{b}}$ & $1.4 \pm 0.22^{\mathrm{b}}$ & 61.11 \\
\hline 3 & AQFA 400mg/kg & $2.4 \pm 0.54$ & $2.4 \pm 0.54$ & $2.4 \pm 0.54$ & $2.4 \pm 0.54$ & $3.4 \pm 0.54$ & 5.56 \\
\hline 4 & AQFA $800 \mathrm{mg} / \mathrm{kg}$ & $1.0 \pm 0.4^{\mathrm{b}}$ & $1.0 \pm 0.40^{\mathrm{b}}$ & $1.2 \pm 0.3 \mathrm{~b}$ & $1.6 \pm 0.46^{\mathrm{b}}$ & $2.2 \pm 0.33^{\mathrm{b}}$ & 38.89 \\
\hline
\end{tabular}

Table 4: Effects of AQFA on wet Fecal pellet output in castor oil-induced diarrhea.

$\mathrm{N}=5, \mathrm{~b}=$ significant compared with control at $\mathrm{P}<0.05$.

\section{Effects of AQFA on Gastrointestinal Motility}

Gastrointestinal motility test revealed that charcoal meal had moved $73.38 \pm 5.18 \%$ of the total length of the intestine in animal treated with normal saline after 30 minutes of ingesting the meal. Furthermore, the standard drug atropine significantly $(\mathrm{p}<0.05)$ reduced the distance travelled by charcoal meal to $37.76 \pm 4.17 \%$, while treatment with AQFA also reduced distance traveled by charcoal meal, with $400 \mathrm{mg}$ of the extract significantly (p < 0.05 ) reducing motility to $53.24 \pm 1.92$, while $800 \mathrm{mg} / \mathrm{kg}$ significantly $(\mathrm{p}<0.05)$ reduced motility to $54.72 \pm 2.57$ (Table 5).

\begin{tabular}{|c|c|c|c|c|}
\hline Group & $\begin{array}{c}\text { Total length of } \\
\text { intestine (cm) }\end{array}$ & $\begin{array}{c}\text { Distance travelled by } \\
\text { marker (cm) }\end{array}$ & $\begin{array}{c}\text { Percentage of intestinal } \\
\text { motility (\%) }\end{array}$ & $\begin{array}{c}\text { Inhibition } \\
\text { rate } \\
\text { (\%) }\end{array}$ \\
\hline NS $(3 \mathrm{mg} / \mathrm{kg})+\mathrm{CM}$ & 96.26 & 70.52 & $73.38 \pm 5.18$ & - \\
\hline Atropine $(0.1 \mathrm{mg} / \mathrm{kg})+\mathrm{CM}$ & 107.38 & 39.84 & $37.76 \pm 4.17^{*}$ & 43.51 \\
\hline $\mathrm{AQFA}(400 \mathrm{mg} / \mathrm{kg})+\mathrm{CM}$ & 102.92 & 54.88 & $53.24 \pm 1.92^{*}$ & 22.18 \\
\hline $\mathrm{AQFA}(800 \mathrm{mg} / \mathrm{kg})+\mathrm{CM}$ & 96.86 & 53.00 & $54.72 \pm 2.57^{*}$ & 24.84 \\
\hline
\end{tabular}

Table 5: Effects of AQFA on Gastrointestinal motility.

Results were expressed as mean \pm standard error of mean; $\mathrm{N}=5$; $^{*}=$ significant compared with control group at $\mathrm{p}<$ 0.05.AQFA: aqueous extract of Ficus asperifolia. CM: charcoal meal. NS: normal saline. 


\section{International Journal of Biochemistry \& Physiology}

\section{Effects of AQFA on Castor oil-induced Enteropooling}

Result shows that treatment with both doses of AQFA significantly $(p<0.05)$ reduced the weight of intestinal content, with $400 \mathrm{mg} / \mathrm{kg}$ dose producing $32.61 \%$ inhibition of intestinal fluid accumulation. Treatment with $800 \mathrm{mg} / \mathrm{kg}$ effected $43.04 \%$ inhibition, while the standard drug loperamide produced $50.43 \%$ inhibition of fluid accumulation. The reduction in volume of intestinal content is in line with the weight as shown in Table 6.

\begin{tabular}{|c|c|c|c|}
\hline Group & $\begin{array}{c}\text { Weight of intestinal } \\
\text { content } \mathbf{( g )}\end{array}$ & $\begin{array}{c}\text { Inhibition rate in volume of } \\
\text { intestinal content (\%) }\end{array}$ & $\begin{array}{c}\text { Volume of intestinal } \\
\text { content (ml) }\end{array}$ \\
\hline $\mathrm{NS}(3 \mathrm{ml} / \mathrm{kg})$ & 2.30 & - & $1.54 \pm 0.17$ \\
\hline Loperamide $(3 \mathrm{mg} / \mathrm{kg})$ & $1.14^{*}$ & 50.43 & $0.6 \pm 0.11^{*}$ \\
\hline $\mathrm{AQFA}(400 \mathrm{mg} / \mathrm{kg})$ & $1.55^{*}$ & 32.61 & $1.06 \pm 0.13^{*}$ \\
\hline $\mathrm{AQFA}(800 \mathrm{mg} / \mathrm{kg})$ & $1.31^{*}$ & 43.04 & $0.74 \pm 0.12^{*}$ \\
\hline
\end{tabular}

Table 6: Showing the effects of AQFA and loperamide on intestinal fluid accumulation.

Results were expressed as mean \pm standard error of mean; $N=5, *=$ significant compared with NS treated group at $\mathrm{p}<$ 0.05. AQFA: Aqueous extract of Ficus asperifolia . NS: normal saline.

\section{Discussion}

Diarrhea accounts for millions of deaths in the world annually. Most people who die from diarrhea actually die from severe dehydration and fluid loss. Therefore, the treatment of diarrhea is an important medical topic [3].

Castor oil is often used to induce diarrhea in animal model research, because castor oil is rich inrecinoleic acid, which causes irritation and inflammation of the intestinal mucosa [11]; stimulate the release of endogenous prostaglandins in the intestine, which in turn cause arachidonic-induced diarrhea, characterized by an increase in intestinal transit time and increase wet fecal pellet output [3].

Aqueous extract of Ficus asperifolia leaves (AQFA), which has not been studied so far for its anti-diarrhea activity was used in the treatment of diarrhea; castor oil induced enteropooling and intestinal motility tests were carried out. The result of this research reveals the antidiarrheal activity of AQFA in experimental animal model. The study shows that AQFA treatment reduced fluid secretion in intestine and intestinal transit time. AQFA was not very effective at a dose of $400 \mathrm{mg} / \mathrm{kg}$ but more effective at a higher dose of $800 \mathrm{mg} / \mathrm{kg}$.

Phytochemical screening of the plant extract revealed the presence of tannins, saponins, steroids, alkaloids which might be responsible for its medicinal/ antidiarrheal activities. In addition, its anti-diarrheal action may be due to the presence of denatured proteins, which form protein tannates. It has been previously demonstrated that protein tannates make the intestinal mucosa more resistant and hence reduce gastrointestinal motility and fluid secretion [1].

In the enteropooling test, AQFA significantly reduce the intestinal fluid content at a dose of $800 \mathrm{mg} / \mathrm{kg}$ body weight. This might be due to inhibition of prostaglandin synthesis. It could also be as a result of increase water and electrolyte re-absorption through the intestinal mucosa [3]. The ability of AQFA to inhibit intestinal fluid accumulation is similar to earlier reports on the antidiarrheal activities of the other plant materials, including root bark of Cordia africana and leaves of Maranta arundinacea Linn [12,13].

The intestinal motility test using activated charcoal as a marker has been used for over 60 years as a simple and effective method of assessing the effects of laxatives on the gastrointestinal tract $[2,14]$. This experiment also revealed that AQFA reduced intestinal motility, and this might suggest that Ficus asperifolia has the ability to relax intestinal muscles. Many drugs and medicinal herbal extracts that are used inthe treatment of diarrhea possess the ability to reduce intestinal contraction and motility $[14,15]$.

Many other plants have also been reported to possess anti-diarrheal activities, such as Moringa oleifera, Albizzialebbeck, Lepidium sativum [16-18].

\section{Conclusion and Recommendation}

This study was carried out to investigate the antidiarrheal activity of aqueous extract of Ficus asperifolia leaf. Base on the beneficial and phytochemical analysis of 


\section{International Journal of Biochemistry \& Physiology}

Ficus asperifolia in the literature and the results of these experiments we concluded that Ficus asperifolia contains pharmacological active substances with significant antidiarrheal activity.

Studies need to be done on other parts of the plant and different fractions of the extract, to know the major fraction responsible for its anti-diarrheal activity. I also recommend that further studies should use more receptor blockers in order to elucidate the mechanism of its antidiarrheal activity which exerts antisecretory and antimotility effects.

\section{References}

1. Akuodor G, Chilaka KC, Maryam I (2011) Evaluation of Antidiarrheal Activity of Ethanol Leaf Extract of Bombax Buonopozense in Different Animal Models. Ibnosina J Med Biomed Sci 3(1): 15-20.

2. Adeniyi OS, Akomolafe RO, Ojabo CO, Eru EU, Olaleye SB (2014) Effect of Zinc treatment on Intestinal Motility in Experimentally Induced Diarrhea in Rats. Niger J Physiol Sci 29(1): 11-5.

3. Adeniyi OS, Omale J, Omeje SC, Edino VO (2017) Antidiarrheal Activity of Hexane Extract of Citrus Limon Peel in an Experimental Animal model. J Integr Med 15(2): 158-164.

4. Oluwafemi AO, Adebola BO, Adewale F, Basiru OA (2016) Antioxidant and Drug Detoxification Potentials of Ficus asperifolia Miq. Extract in $\mathrm{CCl}_{4}-$ Induced Kidney Injuries and Oxidative Damage in Wistar Rats. Adv Biores 7(5): 162-168.

5. Viswanatha GL, Nandakumar R, Shylaja H, Lakshman K (2007) Antidiarrheal Activity of Alcoholic and Aqueous Extracts of Stem ark of Thespesia Populnea in Rodents. Pharmacology online 3: 222-230.

6. Omoniwa BP, Luka CD (2012) Antidiabetic and Toxicity Evaluation of Aqueous Stem Extract of Ficus asperifolia in Normal and Alloxan-Induced Diabetic Albino Rats. Asian J Exp Biol Sci 3(4): 726-732.

7. Ojo OA, Ajiboye BO, Ojo AB, Onikanni SA, Olarewaju OI (2014) Phytochemical, Proximate Analysis and Mineral Composition of Aqueous Crude Extract of Ficus Asperifolia Miq. Journal of Advancement in Medical and Life Sciences 1(1).
8. Sanni M, Friday ET, Alabi OJ, Egwuma BE (2016) Evaluation of Effect of Plant Leaves (Ficus asperifolia ) on the Haemolytic anaemic induced ( with Phenylhydrazine ) in Albino Rat. Asian J Biochem Pharmaceut Res 4(6): 10-21.

9. Ngadjui N, Wtcho P, Nguelefack TB, Kamanyi A (2013) Effects of Ficus asperifolia on Normal Rat Estrus Cyclicity. Asian Pac J Trop Biomed 3(1): 53-57.

10. Teke GN, Kuiate JR, Ngouateu OB, Gatsing D (2007) Antidiarrheal and Antimicrobial Activities of Emilia coccinea (Sims) G. Don Extracts. J Ethnopharmacol 112(2): 278-283.

11. Rupa S, Abdul BA (2014) Evaluation of Antidiarrheal Activity of Ethanolic Extract of Bauhinia variegate (Leguminosae) Stem Bark in Wistar Albino Rats. Int J Pharma Pharmaco Res 2249-6084.

12. Asrie AB, Abdelwuhab M, Shewamene Z, Gelayee DA, Adinew GM, et al. (2016) Antidiarrheal activity of methanolic extract of the root bark of Cordia Africana. J Exp Pharmacol 8: 53-59.

13. Rahman K, Chowdhury AU, Islam MT, Chowdhury A, Uddin ME, et al. (2015) Adv Pharmacol Sci 2015: 257057.

14. Tenorio JAB, Monte DS, Silva T, Ramos CR (2016) Solanum paniculatum root extract reduces diarrhea in rats. Revista Brasileira de Farmacognosia 26 (3): 375378.

15. Sabiu S, Ashafa AOT (2016) Antimicrobial and antidiarreal activities of Pelargonium luridum (Andrews) sweet root extract. J Pharmacologia 7(4): 202-210.

16. Mahesh GS, Paras P, Manish P, Samresh PR, Asish NP (2010) Antidiarrheal Activity of Methanolic Extract of Moringa Oleifera Lam Roots in Experimental Animal Models. Int J Pharmaceuti Res 2(2): 35-39.

17. Neelam B, Dinesh KJ, Pankaj D, Veena N (2012) Evaluation of Antidiarrheal Activity of Ethanolic Stem Bark Extract of Albizzia Lebbeck Linn. in Rats. Songklanakarin J Sci Tech 34(3): 317-322.

18. Divanji MK, Lakshman K, Shylaja H, Viswanatha GL, Rajesh S, et al. (2009) Antidiarrheal Activity of Methanolic Extract of Seeds of Lepidium sativum. J Nat Remedies 9(2): 197-201. 


\section{International Journal of Biochemistry \& Physiology}

(c)

